\title{
Oral Piercing - Pain Or Pleasure?? A Review Article
}

\author{
Dr. Nitin Agarwal $^{1}$, Dr. Haider Iqbal ${ }^{2}$, Dr. Kirti Agarwal ${ }^{3}$, Dr. Saurabh Mathur ${ }^{4}$, \\ Dr. Siddharth Saurabh ${ }^{5}$, Dr. Ankit Saha ${ }^{6}$ \\ ${ }^{I}$ (Department of Oral Medicine \& Radiology,Sardar Patel Post Graduate Institute of Dental and Medical \\ Sciences,India) \\ ${ }^{2}$ (Department of Oral Medicine \& Radiology,Sardar Patel Post Graduate Institute of Dental and Medical \\ Sciences, India) \\ ${ }^{3}$ (Department of Pedodontics \& Preventive Dentistry, Saraswati Dental College, India) \\ ${ }^{4}$ (Department of Oral Medicine \&Radiology, Saraswati Dental College, India) \\ ${ }_{5}^{5}$ (Department of Oral Medicine and Radiology, RKDF Dental College, India) \\ ${ }^{6}$ (Department of Oral Medicine \& Radiology,Sardar Patel Post Graduate Institute of Dental and Medical \\ Sciences, India)
}

\begin{abstract}
Oral piercing is a popular trend, but this fashion statement comes with some serious health risks. The oral and perioral piercing has a long history as part of religious, tribal, cultural or sexual symbolism. Nowadays there is a high incidence of oral and perioral piercing in the adolescent population. Oral and perioral piercing involve the insertion of jewellery into the tongue, lip, cheek, frenum, uvula or other parts of the mouth. This paper covers some of the commonly and uncommonly encountered complications related to oral piercing.
\end{abstract}

Keywords: oral piercing, body art, oral jewellery

\section{Introduction}

A Systematic review of the scientific literature was done and a database of indexed journals (Pubmed, Science direct and Ovid) and search engines like google, was searched. The keywords used were oral piercing, perioral piercing, body art, oral jewellery.

Body $\operatorname{art}^{6}$ is the term usually applied to tattooing and the wearing of jewellery (piercing) in unconventional sites. Piercing of the body and placing of jewellery is an ancient practice, and was typically restricted to the ears, nose and the mouth. ${ }^{1}$ Roman centurions wore nipple rings as a sign of virility and courage, ancient Egyptians pierced their navels to signify royalty. Hindus and Mayans practiced piercing as a part of religious rituals (fig 1), in some Amazonian tribes and in the Surma tribe of Ethiopia, large plates are worn in the lower lip (fig 2), others wear lip plugs. Among those with non-traditional body piercings, the tongue is the most prevalent site followed by the lips. ${ }^{2}$

Body piercing (a form of body modification) is the practice of puncturing or cutting a part of the human body, creating an opening in which jewellery may be worn.

Oral/perioral piercing sites for jewelry placement include the (1) tongue, (2) lips, (3) cheeks, (4) frenum, and (5) uvula.

Most of the intra-oral jewellery used comes in the form of studs, hoops or barbell shaped devices available commercially. ${ }^{4}{ }^{8}$ The jewellery may be surgical grade stainless steel, 14 carat yellow or white gold, niobium or even plastics may be used. ${ }^{4}$

The persons undergoing oral piercing are frequently unaware of the associated risks. Oral and dental complications associated with piercings are categorized as acute (early) or chronic (late). ${ }^{5}$ Acute complications typically arise within 24 hours following insertion of the jewellery into the tongue and are usually confined to injuries of weak tissues. ${ }^{32}$

\section{Post-insertion complications in the early days}

Post operative pain, edema, hemorrhage, tearing of tissue (fig 3), infection, one recent report estimated a $20 \%$ infection rate with intraoral piercing. ${ }^{39}$ The accumulation of dental biofilm and calculus at pierced sites may promote the development of infections. ${ }^{7}$ Interference with speech and mastication ${ }^{9}$, risk of aspiration or inhalation, eczematous rash or allergies, particularly against nickel ${ }^{4,}{ }^{12,}{ }^{28}$ Blood vessels may be torn and vascular nerves damaged, acute hypotension. ${ }^{16}$ Hardee and others ${ }^{42}$ reported a significant loss of blood from hemorrhage following a tongue piercing, which resulted in hypotensive collapse. 


\section{Other and later complications include}

Pain, swelling ${ }^{10}$ and infection ${ }^{50}$, mucosal or gingival trauma, chipped or fractured tooth, increased salivary flow, calculus build-up, foreign body granulomas ${ }^{11,13}$ or allergies, hypertrophic scarring (fig 4), Ludwig's Angina. ${ }^{14,24,25,26}$, bleeding into the pharynx and airway obstruction in anaesthesia ${ }^{15}$, airway problems secondary to swelling of the tongue. ${ }^{30,31,32}$ damage to deeper structures such as nerves and blood vessels. Finally, the potential risk ofaspiration or inhalation of parts of the jewellery if theycome loose should not be overlooked $^{2,32,33}$ (fig 5).Complications during and before administration of general anaesthesia. ${ }^{54,55}$ Tongue or oral piercing ${ }^{40}$ may be complicated by normal oral flora, such as Haemophilus aphrophilus s $^{23,35,36,38}$

One unfortunate individual at risk from hereditary angioedema, developed airways obstruction after tongue piercing. ${ }^{17}$ Another unusual situation involves the possible effect of the jewellery on breath odour. When alcohol elimination was evaluated in two subjects with pierced tongues and in two controls, no differences in the mouth alcohol elimination patterns were observed. ${ }^{18}$

Complications from other types of piercing have included relatively serious adverse effects such as Staph. aureusinfections ${ }^{19}$, osteomyelitis, toxic shock syndrome and endocarditis ${ }^{20}$, Neisseria endocarditis after tongue piercing ${ }^{23}$, Pseudomonas aeruginosa infection ${ }^{21}$ and HIV transmission ${ }^{22,}$, 58 . Although relatively rare, other serious life-threatening complications, such as the development of cerebral brain abscesses have also been reported $^{34}$.

In one study, a group of 63 Californian patients with oral piercing were reviewed and, though complications were not common, tooth chipping was seen in one quarter of patients and a range of other problems was encountered ${ }^{13}$

After healing has occurred, the most common complication is damage to the teeth ${ }^{29}$ and restorations as oral jewellery strikes the teeth in a 'wrecking ball' fashion (fig 6), galvanic currents, airway obstruction, deep cyst formation, lymphocytoma and neuroma. ${ }^{55}$ Hepatitis $\mathrm{B}$ and $\mathrm{C}$ are the most common viruses transmitted by body piercing. ${ }^{41}$ North American National Institutes of Health has identified piercing as a possible vector of transmission of blood borne Hepatitis B, C, D and G. There is also the risk of transmission of Tetanus ${ }^{56}$, syphilis and tuberculosis. $^{55}$

Systematic literature review of 12 studies, 3 in USA, 4 in Italy and the remainder in Taiwan, Korea, Thailand and Africa (subject size from 110 to 13,000). Out of which 9 of the studies, including all US and Italy studies found body piercing to be a risk factor. More recent study in USA, looking at risk factors for acquisition of Hepatitis C (148 pts -88 men, 60 women) demonstrated a high risk of contracting the disease after piercing $^{51}$. (Table 2)

Brooks and colleagues ${ }^{49}$ found documented cases of gingival recession from the increasingly popular behavior of intraoral piercing. ${ }^{47}$ Jewellery-associated recession frequently develops as a narrow, cleft-like defect on the lingual and buccal aspects of the mandibular incisors, ${ }^{43}$ with recession depths of 2-3 mm or more often extending to or beyond the level of the mucogingival junction ${ }^{44}$ (fig 7). Patients with oral jewellery may also be at risk of developing significant loss of periodontal attachment that may lead to tooth loss. ${ }^{45}$ Severe attachment loss can develop even when gingival recession is minimal. ${ }^{5}$ because attachment loss may escape detection, ${ }^{44,43,46}$

Interference with oral health evaluation:Jewelry in the mouth can block the transmissionof X-rays (fig $8,9)$. Clear radiographs, are essential to a complete oral healthevaluation. Jewelry can prevent a radiographfrom revealing abnormalities like cysts, abscessesor tumors.

The restorative method used for a tooth traumatized by tongue jewellery depends on the individual case.

Restorative approaches compatible with the existing tongue jewellery must be considered to increase their clinical longevity. ${ }^{27,47}$ Porcelain onlays, for example, are not suitable in the presence of barbell tongue ornaments because of the brittle nature of porcelain and its low resistance to impact. ${ }^{48}$ Porcelain crowns may also be chipped by tongue jewellery.

In addition, many athletes now display various forms of intraoral piercings, which might lead to a greater risk of dental complications where use of a mouthguard is mandated. ${ }^{53}$

\section{Discussion:}

In this article, we present a brief review of the current literature on potential complications and adverse consequences of tongue and lip piercings. Our objective is to provide a general overview of possible problems that may be encountered by dentists immediately or after some time following piercing. In addition, we highlight the urgent need for dentists and doctors to inform target patients of the risks associated with oral piercings. In fact, the American Dental Association has formulated a position statement opposing oral piercing. ${ }^{52}$

"The American Academy of Pediatric Dentistry strongly opposes the practice of piercing intraoral and perioral tissues and use of jewelry on intraoral and perioral tissues due to the potential for pathological conditions and sequelae associated with these practices" 
The decision to "pierce" is often a personal statement signifying self-expression, fashion trends, risktaking or daring, with no formal religious or societalpurpose.

Dentists are often the first to note any negative effects from the piercing process or from the jewelry itself. A study published in the California Dental Association Journal ${ }^{2}$ indicates that these effects are numerous enough to alert the profession to the problems arising. Oral or facial piercings are now common practice and therefore, dentists should be in a position to advice patients from oral piercings.

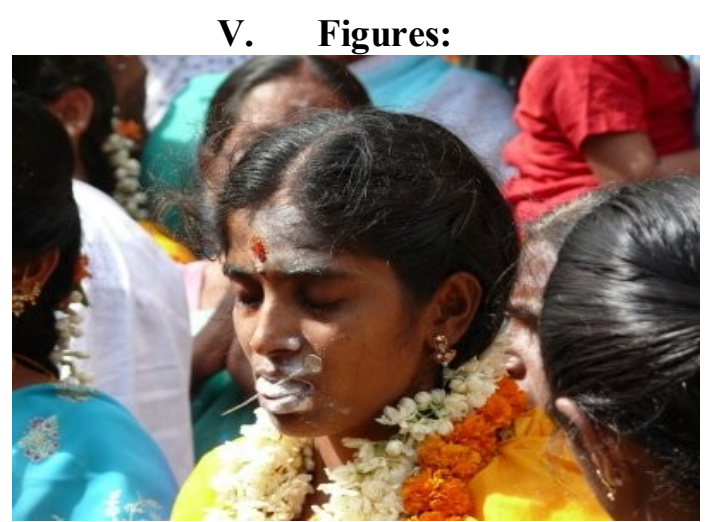

Fig 1. Some people in Southern India pierce the tongue with a skewer to maintain a vow of silence

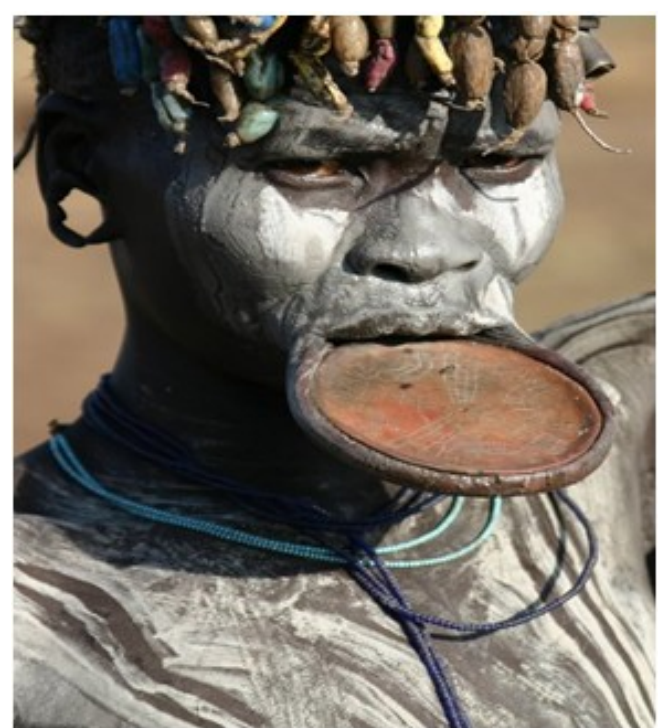

Fig 2.Surma tribe of Ethiopia, large plates are worn in the lower lip.

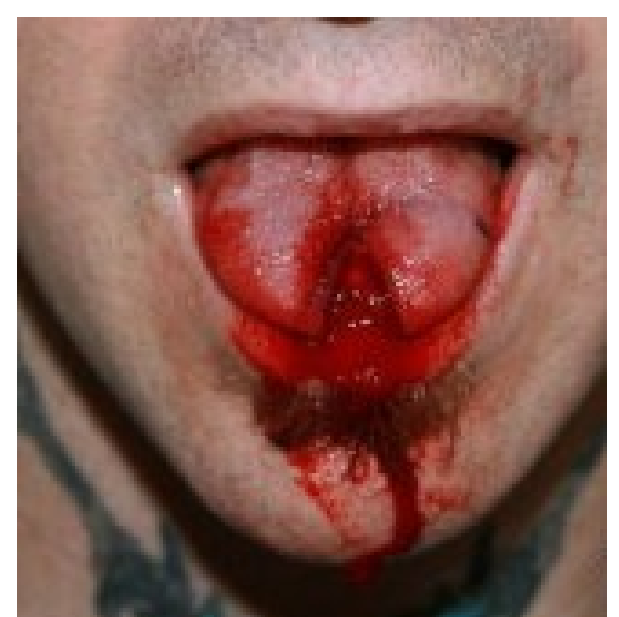

Fig 3. Ripped or torn tissue after piercing 


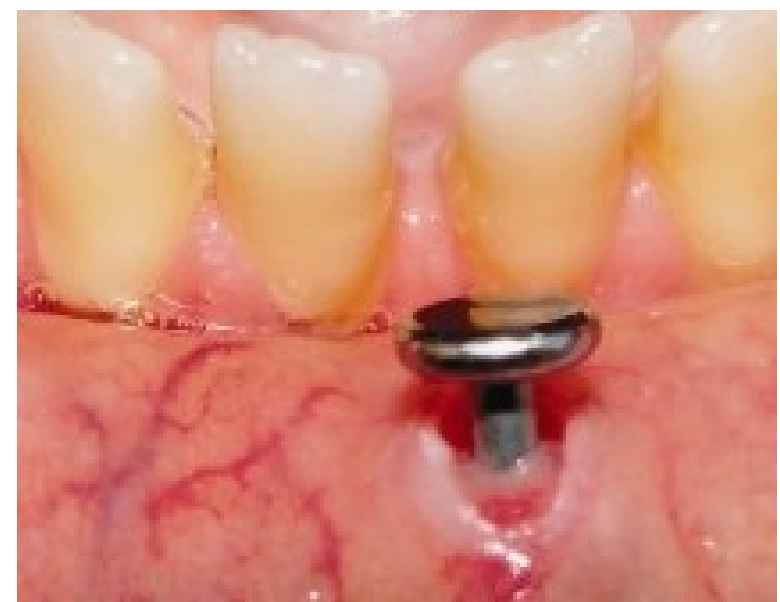

Fig 4. Hypertrophic scarring

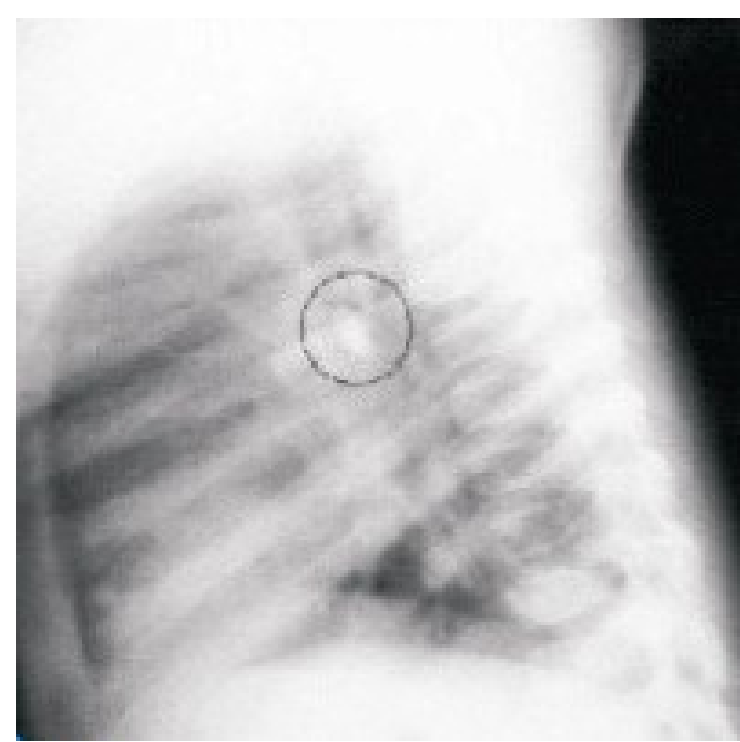

Fig 5. Aspirated mouth jewellery

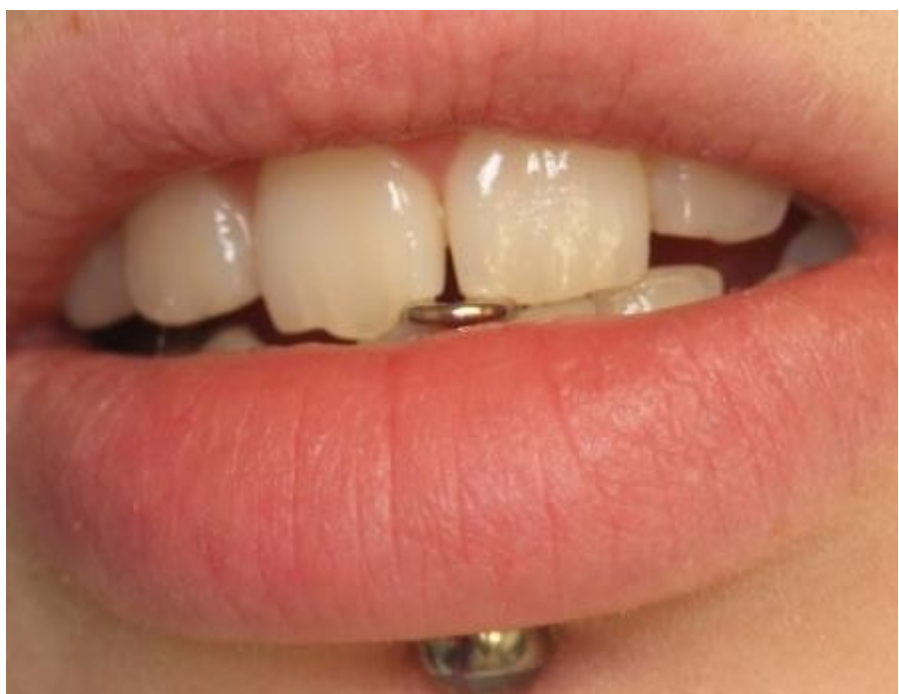

Fig 6. Chipping of incisal edge in a wrecking ball fashion due wearing of intraoral jewellery 


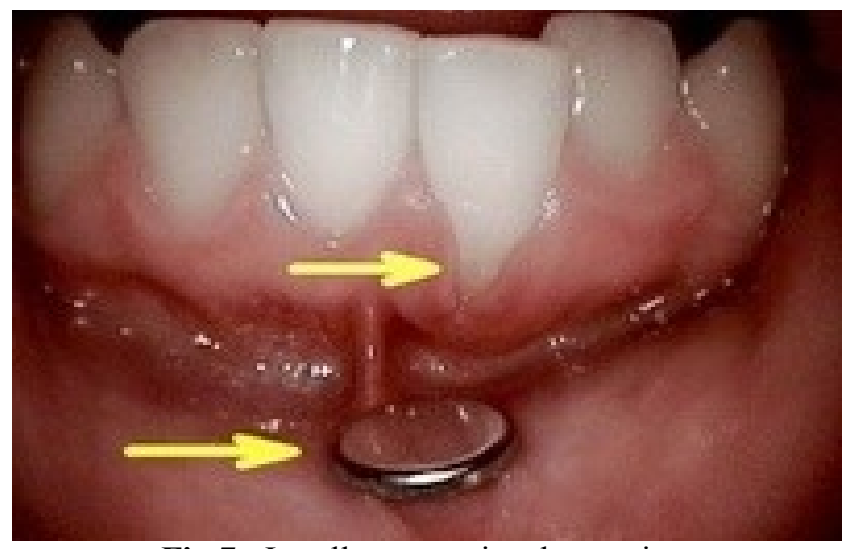

Fig 7. Jewellery-associated recession

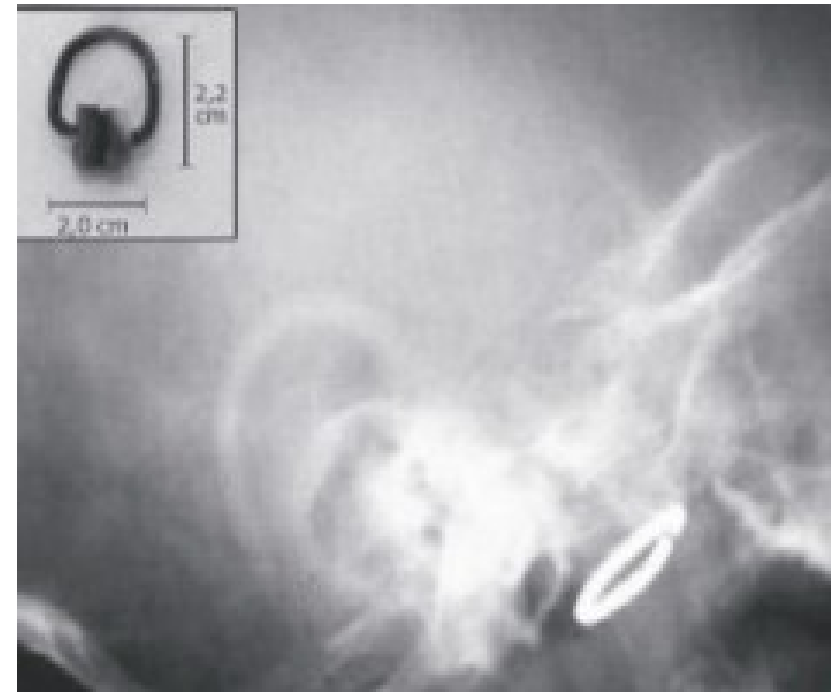

Fig 8. Oral jewellery as a radiographic artifact

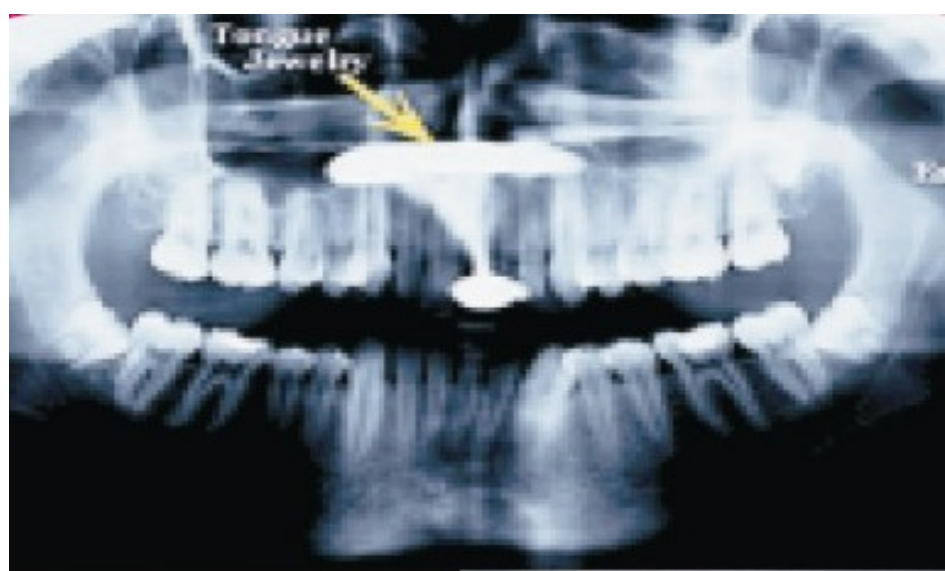

Fig 9. Tongue jewellery interfering with radiographic diagnosis

\section{Tables:}

\begin{tabular}{|l|l|}
\hline Number of cases & $\mathbf{5 1}$ \\
\hline Cases requiring medical/dental attention & 2 \\
\hline Tooth damage & 13 \\
\hline Gingival injury & 4 \\
\hline Infections & 3 \\
\hline Hypersalivation & 8 \\
\hline
\end{tabular}

Table 1.Complications of tongue-piercing.(Boardman and Smith 1997)2. 


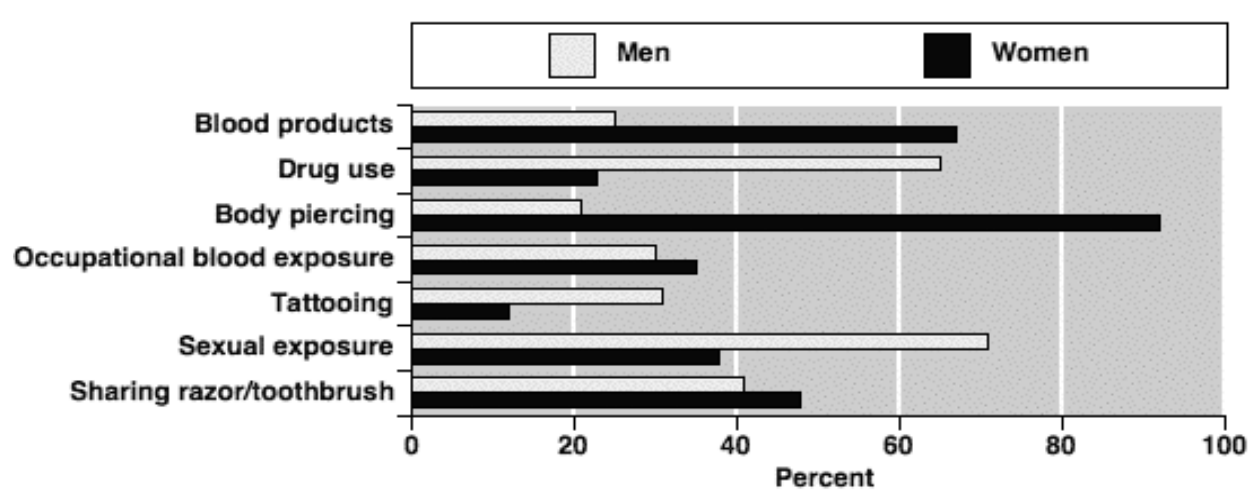

Table 2: Associations between hepatitis $\mathbf{C}$ infection and known risk behaviours

[1]. Ferguson H. Body piercing. BMJ 1999; 319: 1627-9.

[2]. Boardman R, Smith R A. Dental implications of oral piercing. J Calif Dent Assoc1997; 25: 200-7.

[3]. Scully C, Chen M. Tongue piercing (oral body art). Br J Oral MaxillofacSurg 1994;32 (1):37-8.

[4]. Baum MS. A piercing issue. Health State 1996;14(3):14-9.

[5]. Campbell A, Moore A, Williams E, Stephens J, Tatakis DN. Tongue piercing: impact of time and barbell stem length on lingual gingival recession and tooth chipping. J Periodontol2002; 73(3):289-97

[6]. Marcoux D. Appearence, cosmetics, and body art in adolescents. DermatolClin 2000;18:667-73.

[7]. Shacham R, Zaguri A, Librus HZ, Bar T, Eliav E, Nahlieli O. Tongue piercing and its adverse effects. Oral Surg Oral Med Oral Pathol Oral RadiolEndod 2003; 95(3):274-6

[8]. Reichl R B, Dailey J C. Intraoral body-piercing: a case report. Gen Dent 1996; 44: 346-7.

[9]. Armstrong ML, Ekmark E, Brooks B. Body piercing: promoting informed decision making. J SchNurs 1995;11(2):20-5.

[10]. Baker DL, Seymour GJ. The possible pathogenesis of gingival recessions.A histological study of induced recession in the rat.J ClinPeriodontol1976; 3(4):208-19.

[11]. $\quad 11 \mathrm{Ng} \mathrm{KH}$, Siar CH, Ganesapillai T. Sarcoid like foreign body reaction in body piercing: a report of 2 cases. Oral Surg Oral Med Oral Path Oral RadiolEndod 1997;84:28-31.

[12]. Khanna R, Kumar S S, Raju B S et al; Body piercing in the accident and emergency department. JAccidEmerg Med 1999; 16: $418-21$.

[13]. Wright J. Modifying the body: piercing and tattoos. Nursing Standard 1995;10:27-30.

[14]. Parkins C S, Meisner J, Harrison J M. A complication of tongue piercing.Br Dent J 1997; 182: 147-8.

[15]. Wise H. Hypoxia caused by body piercing. Anaesthesia 1999; 54: 1129.

[16]. Hardee P S, Mallya L R, Hutchison I L. Tongue piercing resulting in hypotensive collapse. Br Dent J 2000; 188: 657-8.

[17]. Trachsel D, Hammer J. A vote for inhaled adrenaline in the treatment of severe upper airway obstruction caused by piercing of the tongue in hereditary angioedema.Intensive Care Med 1999; 25: 1335-6.

[18]. Logan B K, Gullberg R G. Lack of effect of tongue piercing on an evidential breath alcohol test. J Forensic Sci1998; 43: 239-40.

[19]. Tweeten S S, Rickman L S. Infectious complications of body piercing. Clin Infect Dis 1998; 26: 735-40.

[20]. Ramage I J, Wilson N, Thompson R B. Fashion victim; infective endocarditis after nasal piercing. Arch Dis Child 1997; 77: 187.

[21]. Staley R, Fitzgibbon J J, Anderson C. Auricular infections caused by high ear piercing in adolescents. Pediatrics1997; 99: 61011 .

[22]. Pugatch D, Mileno M, Rich M. Possible transmission of human immunodeficiency virus type 1 from body piercing. Clinlnfect Dis 1998;26: 767-8.

[23]. Tronel H, Chaudemanche H, Pechier N, Doutrelant L, Hoen B. Endocarditis due to Neisseria mucosa after tongue piercing. ClinMicrobiol Infect 2001;7:275-6.

[24]. Samantha S, Tweeten M, Rickman L. Infectious complications of body piercing. Clin Infect Dis 1998;26:735-40.

[25]. Koenig L, Carnes M. Body piercing, medical concerns with cutting-edge fashion. J Gen Intern Med 1999;14:379-85.

[26]. Folz BJ, Lippert BM, Kuelkens C, Wernaer JA. Hazards of piercing and facial body art: a report of three patients and literature review. Ann PlastSurg 2000;45:374-81.

[27]. Cobb DS, Denehy GE, Vargas MA. Adhesive composite inlays for the restoration of cracked posterior teeth associated with a tongue bar. Practical Periodontics and Aesthetic Dentistry 1998;10:453-60.

[28]. Ehrlich A, Kucenic M, Belsito DV. Role of body piercing in the induction of metal allergies. Am J Contact Dermat 2001;12:151-5.

[29]. Botchway C, Kuc L. Tongue piercing and associated tooth fracture. J Can Dent Assoc 1998;64:803-5.

[30]. Shacham R, Zaguri A, Librus HZ, Bar T, Eliav E, Nahlieli O. Tongue piercingand its adverse effects. Oral Surg Oral Med Oral Pathol Oral RadiolEndod2003; 95(3):274-6.

[31]. Keogh IJ, O’Leary G. Serious complication of tongue piercing. J Laryngol Otol2001; 115(3):233-4.

[32]. Trachsel D, Hammer J. A vote for inhaled adrenaline in the treatment ofsevere upper airway obstruction caused by piercing of the tongue in hereditaryangioedema.Intensive Care Med 1999; 25(11):1335-6.

[33]. Stead LR, Williams JV, Williams AC, Robinson CM. An investigation into the practice of tongue piercing in the South West of England.Br Dent J2006; 200(2):103-7.

[34]. Martinello RA, Cooney EL. Cerebellar brain abscess associated with tongue piercing. Clin Infect Dis 2003; 36(2):e32-4.

[35]. Akhondi H, Rahimi AR. Haemophilusaphrophilus endocarditis after tongue piercing. Emerg Infect Dis 2002; 8(8):850-1.

[36]. Lick SD, Edozie SN, Woodside KJ, Conti VR. Streptococcus viridans endocarditis from tongue piercing.J Emerg Med 2005; 29(1):57-9.

[37]. De Moor RJ, De Witte AM, Delme KI, De Bruyne MA, Hommez GM, Goyvaerts D. Dental and oral complications of lip and tongue piercings.Br Dent J 2005; 199(8):506-9.

[38]. Friedel JM, Stehlik J, Desai M, Granato JE. Infective endocarditis after oral body piercing.Cardiol Rev 2003; 11(5):252-5. 
[39]. McGeary SP, Studen-Pavlovich D, Ranalli DN. Oral piercing in athletes: implications for general dentists. Gen Dent 2002; 50(2):168-72.

[40]. Ram D, Peretz B. Tongue piercing and insertion of metal studs: three cases of dental and oral consequences. ASDC J Dent Child 2000;67:326-9.

[41]. Tweeten SS, Rickman LS. Infectious complications of body piercing.Clin Infect Dis 1998; 26(3):735-40.

[42]. Hardee PS, Mallya LR, Hutchison IL. Tongue piercing resulting in hypotensivecollapse. Br Dent J 2000; 188(12):657-8.

[43]. Brooks JK, Hooper KA, Reynolds MA. Formation of mucogingival defects associated with intraoral and perioral piercing: case reports. J Am DentAssoc2003; 134(7):837-43.

[44]. Campbell A, Moore A, Williams E, Stephens J, Tatakis DN. Tongue piercing: impact of time and barbell stem length on lingual gingival recessionand tooth chipping. J Periodontol2002; 73(3):289-97.

[45]. Brooks JK, Hooper KA, Reynolds MA. Formation of mucogingival defects associated with intraoral and perioral piercing: case reports. J Am DentAssoc2003; 134(7):837-43.

[46]. Knevel RJ. Tongue piercing: part II. Int J Dent Hyg2004; 2(3):145-6.

[47]. Bassiouny MA, Deem LP, Deem TE. Tongue piercing: a restorative perspective. Quintessence Int2001; 32(6):477-81.

[48]. Lesser R. Tongue piercing: a restorative perspective? Todays FDA 2003; 15(11):17-8.

[49]. Brooks JK, Hooper KA, Reynolds MA, Formation of mucogingival defects associated with intraoral and perioral piercing: case reports. JADA 2003;134:837-43.

[50]. Folz BJ, Lippert BM, Kuelkens C, Werner JA. Hazards of piercing and facial body art: a report of three patients and literature review. Ann PlastSurg 2000;45:374-81.

[51]. Bandolier Internet Journal, March 2003, 109-2. Body Piercing - Prevalence and risks.

[52]. American Dental Association, Current Policies, Prevention and Health Education, Policy Statement on Intraoral/perioral Piercing, Chicago, American Dental Association, 1998:743.

[53]. McGeary SP, Studen-Pavlovich D, Ranalli DN. Oral piercing in athletes: implication for general dentists. Gen Dent 2002; 50(2):168-72.

[54]. MandabachM, McCann D, ThompsonG: Body art: Another concern for the anesthesiologist. ANESTHESIOIOG1Y9 98; 88:279 $-80$

[55]. Rosenberg A, Young M, Bernstein R, Albert D, Mandabach M, McCann D, Thompson G. Tongue rings: Just say no. ANESTHESIOLOGY 1998; 89: 1279 - 80

[56]. Wright J. Modifying the body: piercing and tattoos. Nurs Stand 1995; 10:27-30.

[57]. Rethman J, Rethman M. Periodontal screening and recording. Why, when and how. PractHyg 1993; 2:19-23.

[58]. Guierd-Schmid JB, Picard H, Slama L, Maslo C, Amiel C, Pialoux G, et al. Piercing and its infectious complications. A public health issue in France.Presse Med 2000;29:1948-56. 